\title{
Solutions of variational inequality problems in the set of fixed points of pseudocontractive mappings
}

\section{HABTU ZEGEYE and NASSER SHAHZAD}

\begin{abstract}
.
We introduce an iterative process which converges strongly to a solution of the variational inequality problems for $\eta$-inverse strongly accretive mappings in the set of fixed points of pseudocontractive mappings. Our theorems improve and unify most of the results that have been proved for this important class of nonlinear operators.
\end{abstract}

\section{REFERENCES}

[1] Alber, Ya., Metric and generalized projection operators in Banach spaces: Properties and Applications, in Theory and Applications of Nonlinear Operators of Accretive and Monotone Type (A.G. Kartsatos, Ed.), Lecture notes in Pure and Appl. Math., Vol. 178, Dekker, New York, 1996, pp. 15-50

[2] Aoyama, K., Iiduka, H. and Takahashi, W., Weak convergence of an iterative sequence for accretive operators in Banach spaces, Fixed Point Theory Appl., 2006 (2006), Article ID 35390, 13 pp

[3] Browder, F. E. and Petryshyn, W. V., Construction of fixed points of nonlinear mappings in Hilbert space, J. Math. Anal. Appl., 20 (1967), 197-228

[4] Cai, G. and Bu, S., An iterative algorithm for a general system of variational inequalities and fixed point problems in q-uniformly smooth Banach spaces, Optim. Lett., 7 (2013), 267-287

[5] Daman, O. A. and Zegeye, H., Strong convergence theorems for a common fixed point of a finite family of pseudocontractive mappings, Internat. J. Math. Math. Sci., 2012 (2012), Article ID 405315, 18 pp.

[6] Iiduka, H., Takahashi, W. and Toyoda, M., Approximation of solutions of variational inequalities for monotone mappings, Panamer. Math. J., 14 (2004), 49-61

[7] Korpelevich, G. M., The extragradient method for finding saddle points and for other problems, Ekonomika i Matematicheskie Metody, 12 (1976), 747-756

[8] Mainge, P. E., Strong convergence of projected subgradient methods for nonsmooth and non- strictly convex minimization, Set-Valued Anal., 16 (2008), 899-912

[9] Stampacchi, G., Formes bilineaires coercivites sur les ensembles convexes, C. R. Acad. Sciences, Paris, 258 (1964), 4413-4416

[10] Takahashi, W. and Toyoda, M., Weak convergence theorems for nonexpansive mappings and monotone mappings, J. Optim. Theory Appl., 118 (2003), 417-428

[11] Xu, H. K., Another control condition in an iterative method for nonexpansive mappings, Bull. Austral. Math. Soc., 65 (2002), 109-113

[12] Yamada, I., The hybrid steepest-descent method for variational inequality problems over the intersection of the fixed point sets of nonexpansive mappings, in Inherently Parallel Algorithms in Feasibility and Optimization and Their Applications, (D. Butnariu, Y. Censor, and S. Reich, Ed.), North-Holland, Amsterdam, Holland, 2001, 473-504

[13] Yao, Y., Liou, Y. C. and Kang, S. M., Algorithms construction for variational inequalities, Fixed Point Theory Appl., 2011 (2011), Article ID 794203, 12 pp.

[14] Yao, Y. and $\mathrm{Xu}, \mathrm{H}$. K., Iterative methods for finding minimum-norm fixed points of nonexpansive mappings with applications, Optimization, 60 (2011), 645-658

Received: 27.03.2013; In revised form: 05.09.2013; Accepted: 15.01.2014

2010 Mathematics Subject Classification. 47H09, 47J20, 65J15.

Key words and phrases. $\eta$-inverse strongly monotone mapping, pseudocontractive mapping, fixed point, strong convergence.

Corresponding author: N. Shahzad; nshahzad@kau.edu.sa 
[15] Zegeye, H., Ofoedu, E. U. and Shahzad, N., Convergence theorems for equilibrium problem, variotional inequality problem and countably infinite relatively quasi-nonexpansive mappings, Appl. Math. Comput., 216 (2010), 3439-3449

[16] Zegeye, H. and Shahzad, N., Strong convergence theorems for a common zero of a countably infinite family of $\lambda$-inverse strongly accretive mappings, Nonlinear Anal., 71 (2009), 531-538

[17] Zegeye, H. and Shahzad, N., A hybrid scheme for finite families of equilibrium, variational inequality and fixed point problems, Nonlinear Anal., 74 (2011), 263-272

[18] Zegeye, H. and Shahzad, N., Approximating common solution of variational inequality problems for two monotone mappings in Banach spaces, Optim. Lett., 5 (2011), 691-704

[19] Zegeye, H. and Shahzad, N., Convergence of Mann's type iteration method for generalized asymptotically nonexpansive mappings, Computers Math. Appl., 62 (2011), 4007-4014

[20] Zegeye, H. and Shahzad, H., Strong convergence theorems for a solution of finite families of equilibrium and variational inequality problems, Optimization, 2012, DOI:10.1080/02331934.2011.635205, 17 pp.

[21] Zegeye, H. and Shahzad, N., An Iteration to a Common Point of Solution of Variational Inequality and Fixed Point-Problems in Banach Spaces, J. Appl. Math., 2012 (2012), Article ID 504503, 19 pp.

[22] Zegeye, H. and Shahzad, N., Extragradient method for solutions of variational inequality problems in Banach spaces, Abstract Appl. Anal., 2013 (2013), Article ID 832548, 8 pp.

[23] Zegeye, H., Shahzad, N. and Alghamdi, M. A., Strong convergence theorems for a common point of solution of variational inequality, solutions of equilibrium and fixed point problems, Fixed Point Theory Appl., 2012 2012:119, 17 pp.

[24] Zegeye, H., Shahzad, N. and Yao Y., Minimum-norm solution of variational inequality and fixed point problem in Banach spaces, Optimization, 2013, DOI:10.1080/02331934.2013.764522, 19 pp.

[25] Zhang, Q. B., and Cheng, C. Z., Strong convergence theorem for a family of Lipschitz pseudocontractive mappings in a Hilbert space, Math. Comput. Modelling, 48 (2008), 480-485

\author{
DEPARTMENT OF MATHEMATICS \\ UNIVERSITY OF BOTSWANA \\ PvT. BAg 00704, GABorone, BotswanA \\ E-mail address: habtuzh@yahoo.com \\ DEPARTMENT OF MATHEMATICS \\ King AbDulaziz University \\ P. O. B. 80203, JEDDAH 21589, SAUDI ARABIA \\ E-mail address: nshahzad@kau.edu.sa
}

